\title{
PENGEMBANGAN LEMBAR KERJA PESERTA DIDIK BERBASIS LEARNING CYCLE (7E) PADA MATERI PLANTAE
}

\section{THE DEVELOPMENT OF STUDENT ACTIVITY WORKSHEET BASED ON LEARNING CYCLE (7E) ON PLANTAE SUBJECT}

\author{
Muhammad Wahyu Setiyadi \\ Program Studi Pendidikan Biologi STKIP Al Amin Dompu, Indonesia \\ Email: wahysetiyadi074@gmail.com
}

Diterima: 23 Desember 2020. Disetujui: 8 Februari 2021. Dipublikasikan: 3 Maret 2021

\begin{abstract}
Abstrak: Penelitian ini bertujuan untuk mengembangkan Lembar Kerja Peserta Didik (LKPD) berbasis Learning Cycle $7 E$ yang bersifat valid dan praktis. Jenis penelitian ini adalah penelitian pengembangan dengan menggunakan model pengembangan ADDIE yang terdiri dari 5 (lima) tahapan yaitu Analize, Design, Develop, Implement, dan Evaluate. Pengumpulan data dilakukan melaui proses validasi LKPD angket respon siswa dan angket respon guru terhadap LKPD. Data uji coba dianalisis dengan menggunakan analisis deskriptif. Instrument pengumpulan data menggunakan lembar validasi yang dilakukan oleh empat orang validator. Hasil analisis diperoleh validitas pada aspek isi materi, bahasa dan penyajian berturut-turut yaitu sebesar 3,96, 4,07, dan 4,18 dengan rata-rata skor validator 4,07 yang berarti valid dan layak digunakan. Kepraktisan LKPD yang dikembangkan berada pada kriteria respon guru dan siswa sangat kuat yaitu $84,06 \%$ dan $87 \%$ dengan rata-rata $85,53 \%$, sehingga dapat disimpulkan bahwa respon siswa dan guru positif terhadap LKPD yang di kembangkan.
\end{abstract}

Kata Kunci: LKPD, Learning Cycle 7E, Valid, Praktis.

Abstract: this purpose of this study was to develop a Learning Cycle 7e based student Activity worksheet on Plantae concept.the development prodcedures of the research employed ADDIE model which consistented of five stages, namely Analize, Design, Develop, Implement, dan Evaluate. The data were collected throigh student activity worksheet validation process, students and teachers' responses questionnaire. The data were analyzed by using descriptive analysis. The data collection instrument used a validation sheet which was carried out by four validators. The results of the analysis obtained the validity of the aspects of the material content, language and presentation, respectively, namely 3.96, 4.07, and 4.18 with an average validator score of 4.07 which means valid and worthy of use. The practicality of the developed LKPD is in the very strong response criteria of teachers and students, namely $84.06 \%$ and $87 \%$ with an average of $85.53 \%$, so it can be concluded that the student and teacher responses are positive to the developed LKPD.

Keywords: Development, Student Activity Worksheet, Learning Cycle 7E.

\section{PENDAHULUAN}

Berbagai upaya dilakukan pemerintah untuk meningkatkan sumber daya manusia melalui peningkatan kualitas pendidikan. Kurikulum telah ngangalami perubahan beberapa tahun terakhir ini. Perubahan kurikulum merupakan salah satu usaha untuk meningkatkan kualitas pendidikan termasuk perkembangan beberapa metode, model, pendekatan dan strategi pembelajaran. Pendidikan di indonesia sudah seharusnya berupaya untuk menyiapkan peserta didik yang tidak hanya terampil secara kualitatif tapi juga terampil secara kuantitatif, the New Biology menjadi semakin penting untuk pekerjaan ahli biologi, salah satu keahlian tersebut adalah menafsirkan kumpulan data dan mengkomunikasikan interpretasi tersebut [1].

Tujuan pendidikan nasional adalah mencerdaskan kehidupan bangsa merupakan citacita yang terus menerus diupayakan oleh berbagai pihak terutama pelaku pendidikan. Guru merupakan salah satu unsur dalam dunia pendidikan yang mengemban peran yang sangat penting dalam rangka meningkatkan kualitas pembelajaran di sekolah, penempatan peran guru sebagai fasilitator belum dilaksanakan secara optimal. Sebagai fasilitator, guru diharapkan mampu menghadirkan dan atau menciptakan sumber belajar yang dapat menunjang tercapainya tujuan pembelajaran. Sumber belajar dimaknai sebagai informasi yang dapat ditampilkan dan disimpan dalam berbagai bentuk format dan media yang dapat membantu pesrta didik maupun guru dalam kegiatan belajar mengajar (Depdiknas, 2008)

Hakikat pembelajaran biologi selaras dengan tujuan utama dari kurikulum yang diterapkan di indonesia saat ini yaitu kurikulum 2013 dengan pendekattan saintifi yang tidak hanya menilai hasil akhir, melainkan juga menkeankan pada proses pembelajarannya. Dakam kurikulum 
2013 pembelajaran didesain sedemikian rupa agar peserta didik memperoleh pengalaman belajar baik proses mental maupun fisik dengan interaksi antar pesserta didik, peserta didik dengan guru, dengan lingkungan, serta sumber belajar lainnya [2]. Pada kenyataannya, kebanyakan siswa hanya berorientasi pada kemampuan kognitifsaja, dimana siswa menganggap bahwa pembelajaran biologi lebih banyak menghafal dan membosankan sehingga timbul rsa malas untuk belajar biologi. Cimer [3] menjelaskan permaslahan lain dalam biologi yaitu siswa kurang mengetahui hubungan antara apa yang diajarkan di sekolah dengan kehidupan sehari-hari. Permasalahan tersebut disebabkan siswa kurang aktif untuk mengonstruk sendiri pengetahuannya dan guru kurang berperan dalam memfasilitasi peserta didik untuk menghubungkan konsep dengan kehidupan seharihari.

Terkait dengan pengembangan bahan ajar, saat ini pengembangan bahan ajar menjadi kebutuhan yang mendesak. Hal ini merupakan konsekuensi dari perubahan kurikulum lama menjadi kurikulum baru saat ini yakni kurikulum 2013 dengan menggunakan penedekatan saintifik [4]. Salah satu alasan siperlukannya pengembangan bahan ajar adalah ketersediaan bahan ajar yang sesuai dengan kurikulum, yang artinya bahan ajar yang dikembangkan harus sesuai dengn kurikulum dengan mempertimbangkan karakteristik sasaran seperti lingkungan sosial, budaya, tahapan perkembangan siswa, maupun karakteristik siswa sebagai sasaran. Setiyadi dalam penelitiannya juga menyeatakan bahwa pengembangan bahan jara pennting dilakukan oleh pendidik agar pembellajaran lebih efektif, efisien dan tidak melenceng dari kompetensi yang akan dicapainya. Oleh karena itu bahan ajar sangat penting ddikembangkan sebagai upaya pendidik untuk meningkatkan kualitas belajar [5].

Salah satu bentuk bahan ajar yang menjadi bagian penting dalam menjang proses belajar mengajar yaitu lembar kerja peserta didik yang biasa disebut dengan LKPD. LKPD merupakan bahan ajar praktis untuk digunakan dalam proses pembelajaran. LKPD merupakan salah satu perangkat pembelajaran yang sering digunakan dalam proses pembelajaran oleh guru. Menurut Satura [6] LKPD ialah bahan ajar berbentuk cetak yang terdiri dari lembar-lembar kertas berisikan petunjuk pelaksanaan tugas yang wajib dikerjakan oleh siswa atau peserta didik, LKPD ini berfungsi untuk meminimalisir peran guru dan menuntut peserta didik untuk aktifBerdasrkan hasil wawancara kepada guru biologi di MAN 1 Bima, selama ini belum ada yang mengebangkan Lembar Kerja Peserta Didik untuk keperluan mengajar guru itu sendiri. Selam ini guru biologi masih mengandalkan buku paket atai LKPD cetakan yang telah tersedia atau membelinya di toko buku.

Pengembangan LKPD juga harus memeperhatikan model pembelajaran yang digunakan. Adada banyak model pembelajaran yang cocok dengan kurikulum 2013 yang mengandalakan pendekatan saintifik salah satunya adalah modele pembelajaran Learning Cycle $7 E$. Learning Cycle 7E merupakan model pembelajaran yang dikembangkan oleh Eisenkraft pada tahun 2003. Model pembelajaran Learning Cycle 7E melatih peserta didik untuk aktif mengonstruk suatu konsep dan dapat menerapkan konsep tersebut dalam kehidupan sehari-hari [7]. Eisen [8] membagi learning cycle $7 E$ menjadi Elicit, Eugage, Explore, Explain, Elaborate, Evaluate dan Extend.

Secara singkat proses pembelajaran dalam Learning Cycle $7 E$ dimulai dengan mendatangkan pengetahuan awal siswa, melibatkan siswa dalam kegiatan pengalaman langsung yang berhubungan dengan konsep yang dipelajari, memberi siswa kesempatan untuk menyimpulkan dan mengemukakakn hasil dari temuannya, memberi siswa kesempatan untuk menerapkan pengetahuannya pada situasi baru, guru membimbing siswa untuk menerapkan pengetahuan yang telah didapatkan pada konteks baru. Dengan itu proses pembelajaran akan berjalan baik dan memudahkan siswa untuk lebih menguasai temuannya [9]. Beberapa penelitian mengungkapkan bahawa Learning cycle dapat meningkatkan hasil belajar[10], [11], minat belajar dan pemahaman konsep[12], literasi sains[13], pemecahan masalah [14], [15]

berdasarkan alasan-alasan yang sudah dipaparkan, maka disini peneliti melakukan penelitian mengenai validitas dan kepraktisan lembar kerja peserta didik (LKPD) berbasis learning cycle pada materi plantae.

\section{METODE PENELITIAN}

Jenis penelitian ini adalah penelitian pengambangan. Model pengambangan yang digunakan adalah model pengembangan ADDIE yang terdiri dari 5 (lima) tahapan yaitu Analize, Design, Develop, Implement, dan Evaluate [16]. Pemilihan model ADDIE dipilih karena model ini sering digunakan untuk menggambarkan pendekatan sistematis untuk pengembangan instruksional [17]. Uji coba kepraktisan pengembangan produk dilakukan di MAN 1 Bima tahun ajaran 2019-2020.

Untuk mengukur kevalidan instrumen yang digunakan adalah lembar validasi. Validasi Lembar Kerja Peserta Didik terdiri dari aspek kelayakan isi, kebahasaan dan Penyajian. Validasi dilakukan oleh 2 orang dosen ahli dan 2 orang guru biologi. Validasi dilakukan pada tiga aspek yang terdiri dari 
aspek isi materi, aspek bahasa dan aspek penyajian, sedangkan untuk mengukur kepraktisan menggunakan lembar respon siswa dan guru terhadap penggunaan lembar kerja peserta didik. Untuk menganalisi data uji coba pada pengembangan lembar kerja peserta didik digunakan teknik analisis deskriptif. Kriteria kevalidan ditentukan berdarakan tabel 1.

Tabel 1. Kriteria Kevalidan LKPD

\begin{tabular}{cc}
\hline Rerata & Kategori \\
\hline $\mathrm{Va}<1,5$ & tidak valid \\
$1,5 \leq \mathrm{Va}<2,5$ & kurang valid \\
$2,5 \leq \mathrm{Va}<3,5$ & cukup valid \\
$3,5 \leq \mathrm{Va}<4,5$ & valid \\
$4,5 \leq \mathrm{Va}$ & sangat valid \\
\hline
\end{tabular}

Menurut Darwis [18] Kriteria menyatakan LKPD memiliki derajat validitas yang baik, jika minimal tingkat validitas yang dicapai adalah tingkat valid. Jika tingkat pencapaian validitas di bawah valid, maka perlu dilakukan revisi berdasarkan masukan para validator. Selanjutnya dilakukan kembali validasi.

Tabel 2. Kategori Respon Siswa dan Guru

\begin{tabular}{cl}
\hline Rerata $(\%)$ & : Kategori \\
\hline $80 \% \leq \mathrm{R}^{-} \leq 100 \%$ & $:$ Sangat kuat \\
$60 \% \leq \mathrm{R}^{-}<80 \%$ & $:$ kuat \\
$40 \% \leq \mathrm{R}^{-}<60 \%$ & $:$ cukup kuat \\
$20 \% \leq \mathrm{R}^{-}<40 \%$ & $:$ lemah \\
$0 \% \leq \mathrm{R}^{-}<20 \%$ & $:$ sangat lemah \\
\hline
\end{tabular}

Menurut Riduwan [19] Jika $\geq 50 \%$ dari seluruh pernyataan termasuk dalam kategori sangat kuat dan kuat, maka respon dikatakan positif. Jika $<50 \%$ dari seluruh pernyataan termasuk dalam kategori sangat kuat dan kuat, maka dikatakan negatif

\section{HASIL DAN PEMBAHASAN}

Berdasarkan tujuan penelitian dengan mengacu pada metodologi, maka telah dilakukan penelitian pengembangan lembar kerja peserta didik berbasis Learning Cycle 7E. Adapun hasil daril validasi Lembar Kerja Peserta Didik (LKDP) berbasis Learning Cycle $7 E$ dapat dilihat pada tabel 3 .

Tabel 3. Hasil Analisis Kevalidan LKPD Berbasis Learning Cycle $7 E$

\begin{tabular}{lrc}
\hline Indikator & Rata-rata & Kategori \\
\hline Aspek Isi Materi & 3,96 & Valid \\
Aspek Bahasa & 4,07 & Valid \\
Aspek Penyajian & 4,18 & Valid \\
\hline Rata-rata & 4,07 & Valid \\
\hline
\end{tabular}

Dari tabel 3 di ata dapat diketagui bahwa tingkat kevalidan LKPD yang dikembangkan masuk dalam kategori valid dimana pada aspek isi materi mendapatkan nilai rata-rata 3,96 dari keempat validator dengan kategori valid, aspek bahasa dengan nilai rata-rata 4,07 dengan kategori valid dan aspek penyajian LKPD mendapatkan nilai rata-rata 4,18 dari keempat validator dengan kategori valid. Dari ketiga aspek tersebut didapatkan hasil rata-rata kevalidan produk adalah 4,07 dengan kategori valid.

Setelah dilakukannya validasi oleh 2 tenaga ahli dan 2 orang guru selanjutnya lembar kerja peserta didik yang telah dinyatakan valid di uji coba untuk mengetahui tingkat kepraktisan dari lembar kerja peserta didik berbasis Learning Cycle $7 E$ tersebut. Tingkat kepraktisan lembar kerja peserta didik di ukur menggunakan angket respon siswa dan guru yang terdiri dari 2 orang guru dan 31 siswa kelas X Man 3 Bima. Adapun hasil respon siswa dan guru dapat dilihat pada tabel 4 .

Tabel 3. Hasil Analisis Kepraktisan LKPD Berbasis Learning Cycle $7 E$

\begin{tabular}{lcl}
\hline Indikator & $\begin{array}{c}\text { Rata-rata } \\
(\%)\end{array}$ & Kategori \\
\hline Respon Guru & 84,06 & Sangat Kuat \\
respon siswa & 87 & Sangat Kuat \\
\hline Rata-rata & 85,53 & Sangat Kuat \\
\hline
\end{tabular}

Berdaraskan tabel acuan respon guru dan sepon siswa untuk tingkat kepraktisan penggunaan lembar kerja peserta didik berbasis learning cycle $7 E$ termask dalam kategori sangat kuat dengan rata-rata respon siswa adalah $84,06 \%$ dengan kategori sangat kuat, sedangkan respon kedua guru terhadap LKPD yang dikembangkan memiliki nilai rata-rata $87 \%$ dengan kategori sangat kuat. Dari kedua kriteria kepraktisan tersebut didapatkan hasil bahwa rata-rata tespon guru dan siswa adalah $85,53 \%$ yang rearti respon siswa dan guru adalah positif.

Penelitian pengembangan ini dilakukan dengan menggunakan model ADDIE yang terdiri dari 5 (lima) tahapan yaitu Analize, Design, Develop, Implement, dan Evaluate [16]. Pemilihan model ADDIE dipilih karena model ini sering digunakan untuk menggambarkan pendekatan sistematis untuk pengembangan instruksional [17].

Pada tahap Analize dilakukan studi literatur analisis kurikulum dan wawancara terhadap guru biologi yang mengajar di MAN 1 Bima. Berdasarkan hasil wawancara terhadap dua guru biologi MAN 1 Bima selama ini belum ada yang mengebangkan Lembar Kerja Peserta Didik untuk keperluan mengajar guru itu sendiri. Selam ini guru 
biologi masih mengandalkan buku paket atai LKPD cetakan yang telah tersedia atau membelinya di toko biku. Studi literartur dilakukan dengan cara menganalisi kurikulum dalam Permen dikbur No. 59 [20] kelas X pada kurikulum 2013. KI yang dipilih sesuai dengan silabus yaitu KI 1, 2, 3, dan 4 sedangkan KD yang dipilih adalah KD 4.7 yaitu menyajikan data tentang morfologi dan peran tumbuhan pada berbagai aspek kehidupan dalam bentuk laporan tertulis.

Salah satu model pembelajaran yang memfasislitasi siswa untuk memperoleh pembelajaran bermakna adalah Learning Cycle $7 E$. Eisenkarft [8] menjelaskan model pembelajaran Learning Cycle 7E sangat menekankan siswa untuk mengonstruk sendiri pengetahuan awalnya dengan adanya tahap elicit dan memperluas pengetahuan yang telah diperolehnya dengan situasi atau konsep yang baru karena adanya tahap extend.

Berdasarkan hasil dari tahapan Analize tersebut, dilanjutkan ketahap design dimana dalam tahapa ini dilakukan perancangan dan penyusunan desain LKPD[21] berbasis Learning Cycle 7E yang diharapkan dapat memfasilitasi siswa menghubungkan materi yang dipelajari dengan fenomena yang terjadi pada kehidupan sehasi- hari siswa.

Validasi bertujuan untuk memperoleh penilaian serta saran terhadap LKPD yang telah dikembangkan[22]. Berdasarkan hasil pengembangan LKPD yang divalidasi oleh dua orang ahli dalam bidang biologi dan dua orang guru biologi, pengembangan yang dilakukan terhadap LKPD berbasis Learning Cycle 7E termasuk dalam kategori valid dari ketiga aspek yang diukur yaitu aspek isi, aspek bahasa dan aspek penyajian dengan rata-rata 4, 07 dengan kategori valid. Hal ini menunjukan bahawa LKPD berbasi Learning Cycle $7 E$ yang dikembangkan sudah layak untuk dilakukan uji coba atau digunakan dalam proses pembelajaran. Purnamasari[5], dan Setiyadi[4] menyatakan bahwa validasi telah memenuhi kriteria kevalidan jika dalam hal ini instrumen yang dikembangkan telah didasari pada kajian rasional teoritik yang kuat serta memiliki konsistensi secara internal. Hal ini juga didukung oleh Swaitri [23]

\section{DAFTAR PUSTAKA}

[1] Labov, J. B., Reid, A. H., \& Yamamoto, K. R. (2010). Integrated biology and undergraduate science education: A new biology education for the twenty-first century? CBE Life Sciences Education, 9(1), 10-16. https://doi.org/10.1187/cbe.09-12-0092.

[2] Kemendikbud, "Buku Teks Pelajaran Dan Buku Panduan Guru Untuk Pendidikan Dasar Dan Menengah," Peratur. Menteri Pendidik. Dan Kebud. Republik Indones. Nomor 71 Tahun yang menyatakan bahwa perangkat yang berkualitas dan layak digunakan jika telah memenuhi standar kevalidan yang dinilai oleh ahli dan pakar.

Kriteria kepraktisan Lembar Kerja Pesrta Didik Bervasis Learning Cycle $7 E$ di ukur menggunakan respon siswa dan respon guru. Dalam penelitian ini menggunakan dua orang rsponden guru biologi MAN 1Bima dan 31 prang siswa kelas X. Berdasarkan hasil penelitian ratarata respon guru terhadap LKPD yang dikembangkan adalah $84,06 \%$ yang berarti kategori respon dari kedua orang guru biologi sadalah sangat kuat dan menandakan respon positif. Sedangkan respon siswa setelah menggunakan LKPD yang dikembangkan didapatkan rata-rata $87 \%$ siswa memberikan kategori respon sangat kuat dyang menandakan respon siswa terhadap LKPD yang dikembangkan positil. Hal ini disebakan perpaduan LKPD dengan Learning Cycle $7 E$ dapat menuntun siswa unttuk mengonstruksikan pengetahuannya dan mendorong siswa terjun langsung kedalam kegiatan yang ada di dalam LKPD serta learning cycle $7 E$ mampu mendorong siswa intuk mengaitkan pengetahuan denn kejadian yang ada dikehidupan sehari-hari. Hal ini sejalan dengan Eisenkarft [8] yang menyatakan model pembelajaran Learning Cycle 7E sangat menekankan siswa untuk mengonstruk sendiri pengetahuan awalnya dengan adanya tahap elicit dan memperluas pengetahuan yang telah diperolehnya dengan situasi atau konsep yang baru karena adanya tahap extend

\section{KESIMPULAN}

Berdasarkan hasil pengembangan produk Lembar Kerja Pesrta Didik (LKPD) berbasi Learning Cycle $7 E$ didapatkan tingkat kevalidan yang diukur berdasarkan aspek isi, bahasa dan penyajian oleh empat orang validator didapatkan produk yang Valid. Sedangkan tingkat kepraktisan Lembar Kerja Peserta Didik (LKPD) berbasi Learning Cycle $7 E$ yang di ukur berdasarkan respon siswa dan respon guru mendapatkan reepon yang sangat kuat dan mendapatkan respon yang positif.

$$
\text { 2013, } 2013
$$

[3] [Çimer, A. (2012). What Makes Biology Learning Difficult and Effective: Students' Views. Educational Research and Reviews, 7(3), 61-71. https://doi.org/10.5897/ERR11.205

[4] Setiyadi, M. W. (2017). Pengembangan Modul Pembelajaran Biologi Berbasis Pendekatan Saintifik Untuk Meningkatkan Hasil Belajar Siswa. Journal of Educational Science and Technology (EST), 3(2), 102. https://doi.org/10.26858/est.v3i2.3468 
[5] Purnamasari, S., \& Setiyadi, M. W. (2019). Pengaruh zat kimia pada berbagai suhu terhadap denyut jantung katak (rana sp.) Dalam upaya pengembangan buku petunjuk praktikum fisiologi hewan. Bioscientist: Jurnal Ilmiah Biologi, $7(2), \quad 123$. https://doi.org/10.33394/bjib.v7i2.2388

[6] Satura, Y.T., Abdullah, A., \& Rery, R.U. Pengembangan LKPD Aplikatif Integratif Berbasis Inquiri Terbimbing Pada Materi Kesetimbangan Kimia. J. Pijar Mipa, vol. 16, no. 1, p. 64, 2021, doi: 10.29303/jpm.v16i1.1647.

[7] Susilawati, K., Adnyana, B., Bagus, I., \& Swasta, J. (2014). Pengaruh Model Siklus Belajar 7e Terhadap Pemahaman Konsep Biologi Dan Sikap Ilmiah Siswa. In Journal Program Pascasarjana Universitas Pendidikan Ganesha Program Studi IPA (Vol. 4, Issue 1). Ganesha University of Education.

[8] Eisenkraft, A. (2003). Expanding the 5E model. Brodiescience.Pbworks.Com. http://brodiescience.pbworks.com/w/file/fetch/4 8973835/5-8scivocquestho.docx

[9] Muzakir, M. Z., \& Wijaya, P. A. (2018). Pengaruh Model Pembelajaran Learning Cycle 7e Dengan Mind Mapping Pada Mata Pelajaran Ekonomi Terhadap Hasil Belajar Siswa Di Sma Negeri 7 Pekanbaru. Jurnal Pendidikan Ekonomi Akuntansi FKIP UIR, 6(2), 80-89. https://journal.uir.ac.id/index.php/Peka/article/vi ew/2739

[10] Balta, N., \& Sarac, H. (2016). The Effect of 7E Learning Cycle on Learning in Science Teaching: A meta-Analysis Study. European Journal of Educational Research, 5(2), 61-72. https://doi.org/10.12973/eu-jer.5.2.61

[11] Istuningsih, W., Baedhowi, B., \& Sangka, K. B. (2018). The Effectiveness of Scientific Approach Using E-Module Based on Learning Cycle 7E to Improve Students' Learning Outcome AR TI CL E IN FO AB STR A CT. In pdfs.semanticscholar.org. www.ijere.com

[12] Tyas, M. A., Mulyono, M., \& Sugiman, S. (2015). Keefektifan Model Pembelajaran Learning Cycle 7E Terhadap Minat Belajar Dan Pemahaman Konsep Matematika Siswa Kelas X. Unnes Journal of Mathematics Education., 4(3). https://doi.org/10.15294/ujme.v4i3.9053

[13] Khotimah, N., Utami, C., \& Prihatiningtyas, N. C. (2018). Penerapan Model Learning Cycle 7E Untuk Meningkatkan Kemampuan Literasi Matematis Siswa Kelas VIII Pada Materi Prisma. JPMI (Jurnal Pendidikan Matematika Indonesia), 3(1), 15. https://doi.org/10.26737/jpmi.v3i1.457

[14]Lestari, P., \& Rosdiana, R. (2018). Kemampuan Pemecahan Masalah Matematis Siswa melalui
Model Pembelajaran Learning Cycle 7E dan Problem Based Learning. Mosharafa: Jurnal Pendidikan Matematika, 7(3), 425-432. https://doi.org/10.31980/mosharafa.v7i3.156

[15] Darojat, L., \& Artikel, S. (2016). Kemampuan Pemecahan Masalah Siswa Dalam Menyelesaikan Soal Open Ended Berdasarkan Aq Dengan Learning Cycle 7e Info Artikel. Unnes Journal of Mathematics Education Research, 5(1), 1-8. http://journal.unnes.ac.id/sju/index.php/ujme $\mathrm{r}$

[16] Branch, R. M. (2009). Instructional Design: The ADDIE Approach. Department of Educational Psychology and Instructional Technology University of Georgia. https://doi.org/10.1007/978-0-387-09506-6

[17] Setiyadi, M. W. (2018). Desain Model Pengembangan Perangkat Pembelajaran Biologi. NUANSA, 6(2). http://www.stkip-alamin-

dompu.ac.id/ojs/index.php/nuansa/article/vie $\mathrm{w} / 33$

[18] Darwis, M. 2007. Model pembelajaran Matematika yang melibatkan kecerdasan Emosional. Disertasi Program Pascasarjana Program Studi Pendidikan Matematika. Universitas Negeri Surabaya: Tidak diterbitkan.

[19] Riduwan. 2013. Skala Pengukuran VariabelVariabel Penelitian, 10th ed. Bandung: Alfabeta.

[20] Permendikbud Nomor 59 tahun 2014 Tentang Kurikulum SMA/MA. Jakarta.

[21] B. N. Khair, F. P. Astria, K. S. K. Wardani, N. Nurwahidah, and N. L. P. N. Sriwarthini. 2021. Pengembangan LKPD Literasi Sains Berbasis Lesson Study for Learning Community (LSLC)," J. Pijar Mipa, vol. 16, no. 1, p. 136,, doi: 10.29303/jpm.v16i1.2297.

[22] P. R. Mardeni, J. Azmi, and R. Linda.2021. Pengembangan Lembar Kegiatan Peserta Didik (LKPD) Berbasis RMS (Reading, Mind Mapping, and Sharing) pada Pembelajaran Kimia. J. Pijar Mipa, vol. 16, no. $1, \quad$ p. $8, \quad 2021$, doi: 10.29303/jpm.v16i1.1285.

[23] Sawitri, D.W. 2014. et al., "Pengembangan Modul Keanekaragaman Hayati Berbasis Pendekatan Saintifik Untuk Siswa Kelas X SMA Development Of Scientific Approach Based Module of Biodiversity For X Grade of Senior High School Wisanti dan Reni Ambarwati," State University of Surabaya. 